\title{
Czy można zamienić państwa w huby motoryzacyjnej innowacji?
}

\begin{abstract}
Artykuł rozważa hipotezę, iż w obliczu nałożenia się czterech trendów, które będą kształtowały przyszłość przemysłu samochodowego: autonomizacji, urbanizacji, cyfryzacji i elektryfikacji, osiągnięcie sukcesu w przemyśle samochodowym w nadchodzących latach będzie wymagało synergicznej kooperacji pomiędzy sektorem prywatnym i publicznym. W kontekście globalnej konkurencji, której podmiotami są nie tylko pojedyncze przedsiębiorstwa, lecz także całe ekosystemy, państwa będą musiały na nowo przemyśleć swoją zdolność do dostarczania wartości dodanej dla swoich gospodarek. Na przykładzie elektromobilności artykuł proponuje pięć czynników sukcesu dla jej rozwoju w zależności od sytuacji państwa, są to: siła tradycyjnych firm samochodowych, oczekiwania społeczne, potencjał kreacji miejsc pracy, możliwości umiędzynarodowienia i zdolność do inkubacji nowych podmiotów. Ze wstępnej analizy, wymagającej dalszej rozbudowy i weryfikacji, wynika, iż państwa, takie jak Chiny, na starcie wydają się znajdować w uprzywilejowanej pozycji, aby najbardziej skorzystać z potencjału nowej mobilności.
\end{abstract}

Słowa kluczowe: elektromobilność, urbanizacja, autonomizacja, cyberbezpieczeństwo, rola państwa.

\section{Wprowadzenie}

Centralnym celem Nowej Ekonomii Strukturalnej jest przemyślenie na nowo państwa jako koła zamachowego rozwoju. Funkcjonujący od połowy dwudziestego wieku na Zachodzie paradygmat liberalny, którego częścią jest światowy handel, stopniowo przyjmowany przez kraje rozwijające się, a następnie wzmocniony upadkiem komunizmu, doprowadził do podniesienia poziomu życia na całej planecie. Jeżeli wziąć pod uwagę PKB per capita, statystyczny mieszkaniec planety wzbogacił się aż czterokrotnie pomiędzy $1980 \mathrm{r}$. a chwilą obecną, a proporcja najuboższych spadła z 42\% w $1993 \mathrm{r}$. do nawet poniżej 10\% obecnie (Roser, 2018).

Efektem ubocznym globalnego rynku okazały się jednak potężne globalne nierówności. Pogłębiona kryzysem finansowym 2007-2008 r. oraz kryzysem 
strefy euro od 2009 r., rosnąca przepaść pomiędzy garstką coraz bogatszych, najbogatszych i wszystkimi pozostałymi poddała w wątpliwość zasadność globalizacji. Nierówności stały się przedmiotem kontestacji ze strony ekonomistów (Pikketty, 2010). Przełożyły się one również na rosnące zapotrzebowanie wyborców na politykę tożsamości (Fukuyama, 2018).

W efekcie państwa powracają na scenę, choć bardziej trafne byłoby stwierdzenie, że tak naprawdę nigdy z niej nie zeszły, a zwłaszcza te najbardziej skuteczne i rozwijające się. Ale powracająca refleksja nad potrzebą polityki przemysłowej, dawno niewidziane wojny celne, a nawet coraz częstsze korzystanie z polityki sankcji, są w świecie krajów rozwiniętych pewnym novum. Po latach konsumowania owoców wzrostu poprzez politykę społeczną, czerpania recepty na wzrost z konsensusu waszyngtońskiego, wzmacniania więzów regionalnych i budowania reguł globalnych, wszystkie państwa zostały zmuszone na nowo przemyśleć swoją rolę. W szczególności, w jaki sposób stać się wartością dodaną dla swoich gospodarek.

Hipotezą przyjętą w tym artykule jest twierdzenie, że państwa nie mogą tego robić skutecznie, abstrahując od globalnych trendów, które kształtują technologię, biznes, społeczeństwo i nasze otoczenie. Jednym z najciekawszych pól kumulacji tych trendów i nadchodzącej konfrontacji będzie przemysł motoryzacyjny, w którym kluczową rolę odegrają cztery siły: autonomizacja, urbanizacja, cyfryzacja oraz elektryfikacja. Ani firmy, ani pojedyncze państwa nie zdołają wydobyć pełnego potencjału z ich interakcji. Dzięki temu, że synergiczna kooperacja państwa i firm pozostanie bardziej wyjątkiem niż regułą, nagrodą za jej osiągnięcie będzie globalne przywództwo i renta gospodarcza w jednej z najbardziej lukratywnych gałęzi gospodarki na świecie.

\section{Transport autonomiczny}

Początek dwudziestego pierwszego wieku to okres bezprecedensowego przyśpieszenia innowacji. Opisując tę sytuację, szereg autorów oczekuje pojawienia się ,punktu technologicznej osobliwości” (Kurzweil, 2005), w którym inteligencja maszyny wyprzedzi możliwości człowieka i w konsekwencji dojdzie do stopniowej fuzji człowieka i maszyny (Harari, 2018).

Dla przemysłu motoryzacyjnego ten moment nie kojarzy się jednak z fuzją, a wręcz z czymś dokładnie odwrotnym. Człowiek nie będzie musiał kierować samochodem, ponieważ maszyna będzie wystarczająco inteligentna, żeby wykonać tę pracę za niego. Będący owocem technologii cyfrowej i wyrosłych 
z niej sztucznej inteligencji i automatyzacji, transport autonomiczny pobudza wyobraźnię i mobilizuje czołowe zespoły badawcze i zasoby. Większość dużych producentów samochodów przewiduje, że w pierwszej połowie lat 2020 nastąpi przełom i na drogach pojawią się pierwsze pojazdy w pełni autonomiczne. Najpierw będą to pojazdy luksusowe bądź dostawcze poruszające się po przewidywalnych i długich trasach - długodystansowe. Mało kto jednak wątpi, że w perspektywie 2030 r. pojazdy autonomiczne w jakiejś formie będą obecne również w miastach.

Wyzwania technologiczne przestają być jedynie obszarem zarezerwowanym dla firm technologicznych. Tworzą się sojusze pomiędzy tradycyjnymi graczami motoryzacyjnymi i nowymi - technologicznymi, jak np. BMW i Intel, FiatChrysler i Google (Waymo) albo Renault-Nissan i Google. Jak podaje bank Morgan Stanley, pomiędzy 2013 i 2016 r. nastąpił dziesięciokrotny wzrosły zakupów firm technologicznych przez firmy nietechnologiczne (Morgan Stanley, 2018). W charakterze kupujących i hubów innowacji cyfrowej firmy, takie jak Ford, GM czy Uber, dołączyły do tradycyjnych gigantów technologicznych, jak Apple, Google, Facebook czy IBM. Pośród różnych obszarów technologii najszybciej rosnącym segmentem wzrostu stała się sztuczna inteligencja. Jedna z jej głównych aplikacji - rozpoznawanie otoczenia niezbędne dla upowszechnienia samochodów autonomicznych, czyli machine vision - przyniosła w ciągu ostatnich 24 miesięcy jedną trzecią transakcji M\&A w tym obszarze. Najbardziej spektakularną pozostał zakup przez amerykański Intel w 2017 roku izraelskiego start-upu Mobileye produkującego system wizualizacji dla wsparcia kierowcy w prowadzeniu pojazdu. Niedawno zaś, symptomatyczne było przejęcie przez chińskiego giganta technologicznego, Baidu, amerykańskiego start-upu xPerceptions. Dowiódł on bowiem, że wyścig do samochodu autonomicznego przestał być domeną jedynie tradycyjnego świata zachodniego (Hampleton, 2018).

Można się więc spodziewać, że w perspektywie nadchodzących kilkunastu lat pojawiają się pierwsze w pełni autonomiczne pojazdy, które stopniowo upowszechniać się będą w coraz bardziej złożonym środowisku komunikacyjnym, na końcu w miastach. Autonomiczna rewolucja odciąży człowieka z prowadzenia pojazdu, dając tym samym więcej czasu na inne aktywności. Jednocześnie jednak będzie skłaniać do dłuższych podróży, a co za tym idzie do dalszego zwiększania się odległości pomiędzy domem i miejscem pracy. Pod warunkiem nadążenia rozwoju infrastruktury za nowymi możliwościami pojazdu, przełoży się to na dalszy, spektakularny rozwój miast. 


\section{Urbanizacja}

O ile na początku dziewiętnastego wieku jedynie jeden na 50 mieszkańców ziemi mieszkał w mieście, o tyle obecnie aż połowa ludności świata zamieszkuje obszary miejskie. Największe miasta świata w ciągu ostatnich zaledwie kilkudziesięciu lat przeszły spektakularny wzrost. W 1990 r. było 10 megamiast liczących każde ponad 10 mln mieszkańców. Obecnie jest ich już prawie 30 i są zamieszkałe przez niewiele mniej niż 500 milionów ludzi. W perspektywie 2050 roku na całym świecie dwóch na trzech mieszkańców będzie mieszkało w miastach. Oznacza to pomiędzy 6 a 7 miliardów ludzi spośród 9 miliardów zamieszkujących całą planetę (...).

Urbanizacja pociąga za sobą szereg konsekwencji, których skali ani siły oddziaływania nie do końca jesteśmy sobie w stanie wyobrazić. Jedną z najważniejszych będzie odpowiedź na zapotrzebowanie mobilności: z miast „w świat” - jako turyści; pomiędzy miejscem pracy i miejscem zamieszkania - jako pracownicy; pomiędzy miastami - w interesach. Wzrośnie zapotrzebowanie na indywidualizację poruszania się, choć niekoniecznie na własność środków transportu. Wygoda mierzona dostępem i łatwością użytkowania, a nie społeczna aspiracja mierzona posiadaniem, będzie nową normą. Już dzisiaj Nowy Jork posiada znacznie mniejsze nasycenie samochodami niż Warszawa. Samochód, jako narzędzie samorealizacji będzie tracił na znaczeniu wobec pojazdu pozwalającego płynnie przemieszczać się z miejsca A do miejsca B. Sukces Ubera czy Lyfta są już tego przedsmakiem. Firmy samochodowe coraz bardziej zdają sobie $\mathrm{z}$ tego sprawę, a wymowne w tym kontekście są globalne sojusze budowane przez przewoźników miejskich i producentów pojazdów: GM i Lyft, Volvo i Uber.

Banalizacja pojazdu jest nieuchronna, jeśli zdamy sobie sprawę ze skali nadchodzącego wyzwania. Zaopatrzenie w środki transportu, zwłaszcza samochody, jest bardzo nierówne pomiędzy różnymi częściami świata. W Europie na 1000 mieszkańców przypada między 300 a 600 samochodów. W Stanach Zjednoczonych jest to już prawie stosunek jeden do jednego. W Indiach ten stosunek w dalszym ciagu wynosi jedynie 50 samochodów na 1000 mieszkańców. Przy czym trzeba mieć na uwadze, że Indie to kraj szybko rozwijający się, kraj ludzi młodych: w 2030 r. $60 \%$ hindusów będzie miało poniżej trzydziestego roku życia; a w 2050 r. 700 mln ludzi będzie tam mieszkało w miastach. Czy możemy sobie zatem wyobrazić jeszcze więcej samochodów poruszających się po drogach tego kraju? Sadząc po zatłoczonych ulicach New Delhi, Kalkuty, Mumbaju i innych wielkich miast wydaje się to prawie niemożliwe. Zaspokojenie potrzeb i aspiracji mieszkańców miast, np. w Indiach czy w Chinach, w zakresie mobilności stanie się jednym z największych wyzwań XXI wieku. 
W kontekście urbanizacji nie jest jasne czy upowszechnienie pojazdów autonomicznych przyczyni się do rozładowania problemów komunikacyjnych, czy też wręcz przeciwnie - doprowadzi do ich pogłębienia. $Z$ jednej strony, poprzez współdzielenie, pojazd autonomiczny uwolni niezagospodarowany dzisiaj czas korzystania z pojazdów, zwalniając jednocześnie miejsca parkingowe. $\mathrm{Z}$ drugiej zaś - człowiek będzie mógł inaczej zagospodarować czas podczas jazdy, przeznaczając go na rozrywkę, pracę i odpoczynek. Wygoda nieposiadania środka transportu połączona z taniością korzystania z niego może powodować wypieranie transportu publicznego, co jest już częściowo obserwowane w miastach, gdzie upowszechnił się np. Uber.

W efekcie istnieje ryzyko, że miasto jeszcze bardziej się rozciagnie w przestrzeni i ulegnie jeszcze większemu zatłoczeniu w centrach. Wstępne badania opracowane na podstawie doświadczeń z transportem autonomicznym w Bostonie wydają się potwierdzać tę tezę (BCG, 2018). Jakkolwiek w wyniku hipotetycznego upowszechnienia transportu autonomicznego całkowity czas podróży skróci się, jednak w centrum ulegnie on wydłużeniu („efekt zatłoczenia”), podczas gdy w suburbiach w znaczący sposób skróci dojazdy (w konsekwencji prowokując zapewne „efekt rozciągnięcia”). Te badania prowadzone są jednak ceteris paribus, bez zmiany innych parametrów, jak np. polityka w zakresie transportu publicznego, opodatkowanie i ograniczenie wjazdów do centrów miast, dostępność miejsc parkingowych. A jak pokazuje przykład Tokio, możliwe jest bardzo radykalne odciążenie centrum miasta od ruchu samochodowego, dzięki bardzo dobremu dostępowi do transportu publicznego. $\mathrm{Z}$ podobnych przesłanek wychodzą władze Singapuru, które zakładają, że do 2030 roku $80 \%$ mieszkańców miasta będzie miało stację metra lub autobusu w promieniu 5 minut piechotą od miejsca swojego zamieszkania. Najlepiej skonfigurowane systemy miejskie będą zniechęcały do posiadania pojazdu indywidualnego.

W każdym przypadku, interakcja pomiędzy urbanizacją i autonomizacją będzie stanowić wyzwanie. Poprzez autonomizację nastąpi ograniczenie kosztu transportu indywidualnego, co nieuchronnie przełoży się na zwiększony popyt na takie usługi. W efekcie rolę hamulca wezmą na siebie włodarze miast i regulatorzy. Poprzez ograniczenia ruchu, wspieranie transportu publicznego, rozbudowę infrastruktury będą ograniczać pojazdy indywidualne w centrach. Ich sojusznikiem będzie cyfrowa integracja pojazdów i infrastruktury. 


\section{Pojazdy zintegrowane cyfrowo}

Jednym z najbardziej oczywistych megatrendów ostatnich lat, o których dużo się już mówi, jest rosnące znacznie komunikacji i wymiany danych pomiędzy urządzeniami. W szczególności pojazdy integrują się cyfrowo z innymi pojazdami i infrastrukturą. W 2020 roku wszystkie nowe pojazdy będą połączone w sieci (BCG, 2018). To szansa na zwiększenie bezpieczeństwa ruchu, ograniczenie awaryjności. Połączone w sieci pojazdy autonomiczne ograniczą rolę najsłabszego ogniwa w prowadzeniu pojazdu, jakim jest człowiek. Będą mniej narażone na wypadki. Komunikacja z zapleczem serwisowym pozwoli szybciej i lepiej reagować na awarie i problemy techniczne. Ale nie tylko.

Pojazdy zintegrowane cyfrowo i komunikujące się między sobą otworzą nowe perspektywy przed ubezpieczycielami, reklamodawcami, różnymi usługodawcami. Odciążony od uwagi niezbędnej dzisiaj do prowadzenia pojazdu pasażer stanie się atrakcyjnym obiektem działań reklamowych. Możliwość dostarczania produktów do poruszających się pojazdów pozwoli zintegrować drony i pojazdy. Wokół mobilności pojawią się nowe modele biznesowe i nowe przemysły.

Stopniowa digitalizacja wszystkich obszarów aktywności ludzkiej otwiera ogromny potencjał. W kontekście pojazdów autonomicznych i połączonej infrastruktury stawia jednocześnie wyzwanie związane z zapewnieniem bezpieczeństwa danych. Wypadki w przyszłości będą zapewne mniej liczne, ale te które będą miały miejsce mogą być bardziej spektakularne, jeżeli ich powodem będzie działalność terrorystyczna bądź awaria systemu. Cyberbezpieczeństwo stanie się jedną z najbardziej kluczowych dziedzin gospodarki. Potrzeba jej zapewnienia będzie również motywowała do rosnącej interwencji państw. Nie będzie możliwe utrzymanie całościowej ciągłości działania systemu bez jego scentralizowanego monitoringu. $\mathrm{O}$ ile wykreowanie standardów bezpieczeństwa będzie udziałem sektora prywatnego, o tyle ich upowszechnienie będzie rolą regulatora.

Cyfryzacja będzie postępowała ramię $\mathrm{w}$ ramię $\mathrm{z}$ rosnącym znaczeniem energii elektrycznej. O ile mówi się, że XX wiek stał pod znakiem ropy naftowej, o tyle coraz więcej wskazuje na to, że XXI będzie wiekiem elektryfikacji. Energia elektryczna jako napęd rozwoju cywilizacji to również nowa perspektywa dla sektora transportu drogowego. 


\section{Elektryfikacja jako odpowiedź na zanieczyszczenie środowiska i wyzwania klimatyczne}

Szybki rozwój gospodarczy końca XX wieku to również rosnące wyzwanie klimatyczne i środowiskowe. Z perspektywy zobowiązań podjętych przez państwa w ramach porozumienia paryskiego niezbędne stało się ograniczenie emisji dwutlenku węgla w transporcie. Stał się on najszybciej rosnącym źródłem emisji w krajach OECD (IEA, 2018). W szybko rozwijających się krajach Południa miasta stały się siedliskiem smogu i głównym źródłem hałasu. Na całym świecie w niespotykanym tempie pogarsza się jakość powietrza spowodowana właśnie rosnącym ruchem samochodowym. Pociąga on za sobą emisje cząstek sadzy i tlenków azotu. Ponad trzy miliony przedwczesnych zgonów na świecie jest związanych z zanieczyszczeniem powietrza cząstkami sadzy 2,5 PM. Jedna na cztery z tych cząsteczek pochodzi z transportu (CCAC, 2018).

Samochody elektryczne to odpowiedź na rosnace zapotrzebowanie na czystsze miasta bez hałasu. Zastąpienie samochodu spalinowego samochodem elektrycznym zmniejsza emisje tlenków azotu nawet o $80 \%$. Samochody elektryczne pozwalają na zmniejszenie smogu w miastach. Pozwalają na redukcję emisji dwutlenku węgla od 25 do nawet $60 \%$ w zależności od sposobu produkcji energii elektrycznej. Upowszechnienie samochodów elektrycznych w miastach obniży poziom hałasu na ulicach. Dodatkowo samochód elektryczny może być bardzo wygodny. Jak pokazują badania na rynkach, gdzie doszło do ich upowszechnienia - np. w Norwegii czy w Kalifornii - kierowcy chętnie ładują swój samochód w domu, bez konieczności korzystania ze stacji paliw (IEA, 2018). W wielu krajach ładowanie w nocy dodatkowo obniża koszt użytkowania samochodu. Nie ma manualnej skrzyni biegów, co jest szczególnie wygodne podczas jazdy w mieście.

Do niedawna, jeszcze do pierwszych lat XXI wieku, pojazdy elektryczne nie miały szans na upowszechnienie ze względu na: zaporowy koszt baterii, brak infrastruktury ładowania, niechęć tradycyjnych producentów samochodowych do kanibalizowania swojego know-how, brak rynku wtórnego. Wiele jednak wskazuje, że to właśnie one wkrótce staną się konkurencyjne kosztowo dla tradycyjnych pojazdów spalinowych. Spośród paliw alternatywnych to elektromobilność upowszechni się najszybciej. Pozostawi ona w tyle pojazdy wodorowe, jak również napędzane biopaliwami i gazem, choć oczywiście nie można wykluczyć, że kolejne innowacje przełamią z czasem i ten trend.

Stanie się tak dlatego, że koszt posiadania samochodu to nie tylko koszt zakupu, lecz także koszt paliwa, napraw i serwisu. Już obecnie poruszanie się 
samochodami elektrycznymi jest tańsze i wygodniejsze niż autami spalinowymi. Mniejsze są koszty napraw i serwisu, bo samochody elektryczne są mniej złożone (silnik i skrzynia biegów to około 1000 części mniej), nie potrzebują wymiany oleju ani filtrów. Jednak kluczem do ich upowszechnienia stanie się spadający koszt baterii litowo-jonowych, który przełoży się na niższą cenę zakupu samochodu elektrycznego. Stanowiące $40 \%$ kosztu jego wyprodukowania baterie tanieją o 10-15\% rocznie (IEA, 2018). W efekcie, ocenia się, że w perspektywie 2020-2022 całkowity koszt posiadania samochodu elektrycznego - liczony łącznie jako koszt zakupu i użytkowania w okresie co najmniej pięcioletnim - będzie niższy od samochodu spalinowego. Rynek będzie rozwijał się coraz szybciej, przechodząc ze wzrostu liniowego w wykładniczy, co już jest zauważalne: aby sprzedać pierwszy milion samochodów elektrycznych potrzeba było 60 miesięcy, drugi milion zabrał tylko 17 miesięcy, trzeci to już 10 miesięcy, a czwarty milion został osiągnięty w sierpniu 2018 roku w 6 miesięcy. W pespektywie globalnej ocenia się, że z obecnego $1 \%$ pojazdów, ,elektryki” osiągną pomiędzy 20 a $40 \%$ udziału w rynkach. W samej Europie w 2030 roku będzie to $5 \mathrm{mln}$ nowych samochodów elektrycznych rocznie. W perspektywie 2040 roku pomiędzy 250 a 500 milionów pojazdów, spośród 2 miliardów na świecie, będzie napędzanych energią elektryczną.

\section{Rozwój przemysłu motoryzacyjnego a rola państwa}

Środki transportu, przede wszystkim zaś samochód indywidualny, będą zatem przez najbliższe dziesięciolecia podlegały intensywnej (r)ewolucji. Rosnąca urbanizacja połączona z digitalizacją i autonomizacją wymusi nowe modele biznesowe i regulacyjne. Następować będzie wypieranie samochodu ze sfery własności do sfery korzystania. Postęp technologiczny umożliwi ewolucję napędu od silnika spalinowego do elektrycznego.

Z pojazdów przyszłości będziemy korzystać na inne sposoby niż dotychczas, ewoluując od własności do współdzielenia. Ocenia się, że w 2025 roku będzie 80 milionów użytkowników car-sharingu na świecie. W perspektywie $2030 \mathrm{r}$. jedna trzecia podróży w Indiach będzie odbywanych za pomocą współdzielonych środków transportu, co postawi ten kraj w roli lidera tego typu komunikacji. Współdzielenie zakorzeni się jako alternatywa dla rozbudowania transportu publicznego, który wśród krajów rozwijających nie cieszy się należną mu popularnością, wymagając długookresowego planowania przestrzennego i środków na inwestycje. 
Elektryczne, ładowane w nocy pojazdy przyszłości będą poruszały się w sposób zautonomizowany po ustalonych trasach. Upowszechnią się zróżnicowane pojazdy dostawcze, od ciężarowych, poprzez półciężarowe, po transport ostatniej mili, być może łącznie z dronami. Podobnie jak pierwsze samochody wyglądem przypominały dorożki, podobnie pojazd przyszłości nie musi przypominać swojego dziadka z XIX ani ojca z XX wieku. Pomiędzy pojazdem rodzinnym a autobusem otworzy się przestrzeń na małe, autonomiczne pojazdy dowożące na krótkie odległości: pomiędzy miejscem zamieszkania i metrem; w obrębie dzielnicy. To szansa dla nowych firm, które skoncentrują się tylko na samochodach elektrycznych. W szczególności powstanie niskobudżetowego samochodu elektrycznego radykalnie zmieni obraz rynku.

Samochody elektryczne ograniczą zależność od ropy. Wiele państw uzna ten argument za wystarczająco atrakcyjny, aby wesprzeć upowszechnienie pojazdów elektrycznych.

Państwo będzie odgrywało kluczową rolę w dostępie do nowego potencjału wartości. Nie będzie autonomicznego transportu bez wyrafinowanych regulacji prawnych, definiujących odpowiedzialność stron i standardy bezpieczeństwa. Współdzielenie transportu zyska znacznie na przywilejach, w tym fiskalnych. Elektryfikacja nie będzie możliwa bez determinacji legislatorów i początkowego dofinansowania ze środków publicznych. Cyfrowa mobilność będzie uwarunkowana dostępem do wyrafinowanych kompetencji cyberbezpieczeństwa, które jako dobro publiczne będzie w stanie zgromadzić jedynie wspólnota na poziomie państwa. Nie będzie nowych, wysoko płatnych miejsc pracy bez zaawansowanych systemów edukacyjnych.

Otworzą się nowe modele biznesowe, stare zostaną doprowadzone do ruiny, dając szansę nowym graczom lub ugruntowując przewagę istniejących. Nowa mobilność, cyfrowa, autonomiczna, elektryczna i współdzielona to perspektywa na rozwój dla przemysłu motoryzacyjnego. Szacuje się, że w ciągu nadchodzących 20 lat przybędzie 2500 miliardów dolarów nowych przychodów. W tym samym czasie dotychczasowe technologie praktycznie nie drgną. Cały, $40 \%$ wzrost sektora przypadnie na nową mobilność, otwierając „błękitny ocean” (...) dla pionierów. W tradycyjnym biznesie samochodowym brak dynamiki wzrostu będzie oznaczać regres (BCG, 2018). Więcej prostej konkurencji, siłą rzeczy kosztowej, kontynuacja raczej niż przełom ugruntują „,czerwony ocean” jako przestrzeń konkurencji dla tradycyjnego przemysłu samochodowego.

Najlepsi pionierzy zbiorą rentę pierwszeństwa. Państwa, które w sposób synergiczny przekształcą swój przemysł w kierunku nowej mobilności zyskają szansę na światowe przywództwo. Firmy, które skorzystają na wyobraźni swoich zarządzających i legislatorów wykorzystają potencjał rodzimych rynków i aktywów dla 
zbudowania globalnej przewagi. Nowa mobilność przewartościuje dotychczasowy pejzaż konkurencyjny. Jakkolwiek tradycyjni producenci samochodowi pozostaną dobrze spozycjonowani, aby wychwycić potencjał nowej wartości, to nie jest im on dany automatycznie. Elektryfikacja pojazdu postawi wszystkich na nowej linii startu. Nowe modele biznesowe otworzą nowe przestrzenie konkurencji. Nowi producenci, m.in. tacy jak Tesla, NIO, Faraday Future, Lucid mają w tym nowym wyścigu unikalną szansę na równorzędny start razem z BMW, Renault i Fordem. Może również okazać się, że elektromobilni innowatorzy - poprzez unikalną szansę na brak nagromadzonego bagażu zaszłości tradycyjnych producentów - zyskają nawet na starcie przewagę w tym nowym, globalnym rozdaniu. W końcu przekraczająca kapitalizację GM wycena Tesli też o czymś świadczy.

\section{Szanse dla nowych producentów}

Połączenie biznesowej, społecznej i technologicznej zmiany to niepowtarzalny moment dla nowych producentów. Dominacja silnika spalinowego utrwaliła na przestrzeni XX wieku określoną strukturę rynku. Jednak producenci klasyczni nie mają interesu w szybkiej elektryfikacji transportu. $\mathrm{Z}$ jednej strony potrzebują czasu na zamortyzowanie inwestycji w auta spalinowe. $Z$ drugiej - utraca nawet do 50\% marży pochodzącej obecnie z serwisu. To właśnie poprzez części zamienne uzyskują swoją rentowność w całym cyklu życia pojazdu. W sytuacji, kiedy pojazd elektryczny jest znacząco prostszy, nie będą w stanie wykorzystywać swoich aktywów produkcyjnych ani dostawców.

Ocenia się, iż w samej tylko grupie Volkswagen elektryfikacja pojazdów spowoduje ograniczenie zatrudnienia o co najmniej 10\%, czyli 60 tys. pracowników. Broniąc się, klasyczni producenci stosują wszelkie dostępne, a nawet nielegalne metody, aby ograniczyć tempo tej transformacji. Namacalnym tego dowodem może stać się postępowanie o zmowę uruchomione we wrześniu 2018 roku przez Komisję Europejską o ograniczenie upowszechniania czystego transportu przez europejskich producentów. Prowadzą więc oni elektryfikację w sposób selektywny, koncentrując się na segmentach niemasowych. W mniejszym stopniu starają się o zdominowanie nowych obszarów, w większym zaś - walczą o utrzymanie dotychczasowych.

Dodatkowym wyzwaniem jest dla nich bagaż nieefektywności, który za sobą niosą historycznie. Rozbudowane sieci dilerskie okazują się w dobie Internetu nieefektywne i kosztowne, czego ilustracją jest sposób sprzedaży bezpośredniej, jaki stosuje Tesla. Struktura zatrudnienia w fabrykach jest niedostosowana do 
samochodów elektrycznych ze względu nie tylko na skalę, lecz także na kompetencje. Umiejętności w zakresie energochemii, elektryki, informatyki niezbędne dla produkcji bateryjnych „komputerów na kółkach” zastępują klasyczne umiejętności w zakresie mechaniki i silników.

Nowa mobilność pozwoli na stworzenie wysoko płatnych miejsc pracy. Każda nowa fabryka samochodów elektrycznych bądź złożonych komponentów oznacza setki, a często tysiące nowych miejsc pracy. Każde miejsce pracy u producenta samochodów pozwala na utworzenie dodatkowych 3-5 miejsc pracy poza fabryką, np. u poddostawców. Nie tylko wysokie wynagrodzenia, lecz także kompetencje w zakresie automatyzacji, sztucznej inteligencji czy cyberbezpieczeństwa przyniosą dodatkowe korzyści w innych obszarach: inteligentnego miasta, energetyki, bezpieczeństwa, IT bankowości, ubezpieczeniach. Firmy nowej mobilności przyczynią się do promocji wizerunku swojego państwa.

Uruchomienie rentownej produkcji na poziomie kilkuset tysięcy egzemplarzy to inwestycja rzędu kilku do kilkunastu miliardów dolarów, która jakkolwiek ryzykowna, może już być atrakcyjna dla kapitałodawców, a na pewno dla państw i regionów, które na nie postawią. Wymownym przykładem tego jest wspierane publicznymi środkami, ale również ogromną kapitalizacją powstanie Tesli, w ślad za którą idą obecnie kolejni.

\section{Elektryfikacja transportu i strategie wybranych państw}

Nie wszystkie państwa i nie każdy ekosystem gospodarczy będzie jednak w stanie skorzystać z opisanej (r)ewolucji. Większość państw ugrzęźnie w nieefektywnościach charakteryzujących biurokrację lub w ociężałościach systemu politycznego. Mało jest miejsc na świecie, gdzie możliwe jest zgromadzenie wystarczającego kapitału do inkubacji nowych, ryzykownych biznesów. Na wielu dojrzałych rynkach zmiana technologiczna napotka opór współczesnych „luddystów”, dla których będzie ona niosła za sobą utratę dotychczasowego zajęcia. Nawet jeśli lokalnie wykiełkują nowe podmioty, a system regulacyjny okaże się wystarczająco sprawny, aby je wesprzeć, w rysującym się na horyzoncie świecie gospodarczej fragmentaryzacji nie jest pewne czy uda się je wyprowadzić na rynki globalne, dając szanse na rozwinięcie skrzydeł. Zaistnieje wiele przeszkód, które zahamują uruchomienie synergicznej kooperacji pomiędzy państwem i firmami, znajdującymi się w jego obszarze wpływów.

Ujęcie wszystkich możliwych współzależności pomiędzy wymienionymi czterema trendami i strategiami państw jest wzywaniem wykraczającym poza poje- 
dynczy artykuł. Chcąc jednak zbudować pewien zespół hipotez - czynników sukcesu synergicznej kooperacji - opisana poczwórna rewolucja została zredukowana tylko do zmiany technologicznej, czyli przejścia z pojazdu spalinowego do elektrycznego.

Dla uzyskania pełnego potencjału rozwoju wynikającego z elektryfikacji napędów pojazdów zakłada się zatem, iż skuteczna interakcja pomiędzy sektorem publicznym i prywatnym będzie zależna od kombinacji co najmniej pięciu czynników: siły tradycyjnych firm samochodowych, odpowiedzi na oczekiwania społeczne, potencjału tworzenia nowych miejsc pracy, możliwości umiędzynarodowienia oraz zdolności do inkubacji nowych graczy. Każdy z nich został poniżej zarysowany na przykładzie siedmiu państw: Niemiec, Chin, USA, Francji, Wielkiej Brytanii, Norwegii i Polski. Wybór krajów jest arbitralny, a opis sytuacji w każdym z nich nie pretenduje do zupełności, a jedynie służy postawieniu pewnych hipotez, które będą mogły stanowić podstawę do dalszych badań.

Największym wyzwaniem na drodze do skorzystania z potencjału elektrycznej mobilności jest sita tradycyjnych firm samochodowych. Ponieważ skuteczna zmiana technologiczna wymaga płynnej i synergicznej kooperacji pomiędzy państwem i sektorem prywatnym, więc państwa, w których funkcjonuje tradycyjny przemysł motoryzacyjny będą poddane tendencjom do jej wyhamowania. W szczególności, silne przewagą 150 miliardów euro nadwyżki eksportowej w przemyśle motoryzacyjnym, osiągniętą z tytułu nagromadzonego know-how w zakresie silnika spalinowego, Niemcy będą traktowały elektryfikację transportu w kategoriach bardziej defensywnych niż ofensywnych. Z kolei Chiny będą w tym upatrywały szansy, aby „przeskoczyć, nie doganiając”, czyli wykreować własny przemysł w nowej niszy technologicznej w opozycji do dzisiejszych potentatów. Kraje jak Polska, Norwegia czy Wielka Brytania - pozbawione rodzimych producentów - będą w zmianie technologicznej widziały możliwość inkubacji nowych podmiotów. Stanowiska USA i Francji, pozycjonujących się na przeciwległych biegunach w zakresie ambicji klimatycznych, będą do pewnego stopnia trybutariuszami tych wyborów.

Rozwój elektromobilności będzie postępował najlepiej tam, gdzie będzie odpowiedzia na oczekiwania społeczne. Kraje, w których społeczeństwa borykają się z zanieczyszczeniem powietrza, takie jak Chiny, Polska nie będą miały trudności z przekonaniem swoich społeczeństw do zalet czystego transportu. Również gęstość zaludnienia megamiast, takich jak Paryż, pomoże zbudować dla niego poparcie. Świadomości środowiskowa i klimatyczna przyczynią się do jego upowszechnienia, przynajmniej w niektórych stanach USA (np. w Kalifornii), w Niemczech i Norwegii. Przeszkodą będą możliwości finansowe społeczeństw, tonując rozwój kosztownych w zakupie pojazdów elektrycznych w uboższych 
społeczeństwach, jak Chiny czy Polska, a promując ich upowszechnienie w bogatych, jak Norwegia czy Kalifornia.

Potencjat tworzenia nowych miejsc pracy będzie największy w dynamicznie rozwijających się, zwłaszcza pod względem przemysłowym, krajach, jak Polska i Chiny. Dla Niemiec i Francji bilans w zakresie zatrudnienia będzie początkowo ujemny, powodując opór związków zawodowych, skonfrontowanych z utratą tradycyjnych miejsc pracy. Norwegia, Wielka Brytania będą miały utrudnioną sytuację. Pierwszy z nich ze względu na małą skalę przemysłu samochodowego, drugi ze względu na brexit, który pociąga za sobą znaczną niepewność dla firm lokujących się na Wyspach. Jednak ten ostatni argument może również wzmocnić determinację rządu do poszukiwania wszelkich możliwych sposobów wykreowania nowego zatrudnienia. Zważywszy na znaczenie i różnorodność rynku amerykańskiego globalna rewolucja technologiczna będzie tam wspierała miejsca pracy, nawet jeśli bilans w obrębie poszczególnych stanów będzie diametralnie zróżnicowany.

Dla wszystkich omawianych krajów bardzo ważne są możliwości umiędzynarodowienia, rozumiane jako zdolność do nawiązania produktywnych kooperacji międzynarodowych, jak również budowa wizerunku kraju, który pozytywnie rezonuje z elektryfikacją transportu. Szczególnie zyskają pionierzy, tacy jak Norwegia oraz największy rynek - Chiny. Niespójność w zakresie polityki klimatycznej pomiędzy rządem federalnym i niektórymi stanami, w szczególności Kalifornią, będą powodowały, że możliwość wykorzystania elektromobilności dla promocji Stanów Zjednoczonych nie będzie jednoznaczna.

Pozostaje jeszcze zdolność do inkubacji nowych graczy, która jest jednym z najtrudniejszych warunków do spełnienia, a jednocześnie warunkiem koniecznym dla sukcesu. W najlepszej sytuacji są gospodarki dojrzałe, o silnych kompetencjach, zaawansowanych więzach kooperacyjnych i posiadające zasoby kapitału wysokiego ryzyka, w szczególności USA. Przewagę mają również kraje, które obrały diametralnie inny model rozwoju, takie jak Chiny, mające silną tradycję etatyzmu, a jednocześnie narzędzia do jego ekspresji w sferze gospodarki. W najtrudniejszej sytuacji są kraje Unii Europejskiej skrępowane wspólnymi zasadami ochrony konkurencji. Francja, skonfrontowana od lat z wyzwaniami deindustrializacji, nie ma narzędzi inkubacji podmiotów przemysłowych. Gospodarka Niemiec jest również stosunkowo tradycyjna, choć udaje się zbudować nowe podmioty również w obszarze elektromobilności, choćby na potrzeby niemieckiej poczty. Znajdując się na środkowym etapie brexitu, Wielka Brytania nie będzie miała pełnej zdolności do wykorzystania wszystkich szans, jakie ofiaruje jej potencjał gospodarki i dostęp do finansowania. Na słabej pozycji są również Polska i Norwegia. 
Powyższe rozważania zostały ujęte w formie tabelarycznej, gdzie przyporządkowano im oceny na skali od najmniej sprzyjającej $(-)$, poprzez neutralną $(0)$ po dobrą $(+)$ i bardzo dobrą $(++)$.

Tabela 1. Schematyczna ocena perspektyw rozwoju elektromobilności dla wybranych państw

\begin{tabular}{|l|c|c|c|c|c|c|}
\hline & $\begin{array}{c}\text { Brak naturalnych } \\
\text { przeciwników } \\
\text { hamujących } \\
\text { rozwój } \\
\text { elektromobilności }\end{array}$ & $\begin{array}{c}\text { Odpowiedź } \\
\text { na wyzwania } \\
\text { i możliwości } \\
\text { społeczne }\end{array}$ & $\begin{array}{c}\text { Możliwośćc } \\
\text { tworzenia } \\
\text { nowych miejsc } \\
\text { pracy }\end{array}$ & $\begin{array}{c}\text { Potencjal } \\
\text { w sferze } \\
\text { międzynarodowej }\end{array}$ & $\begin{array}{c}\text { Zdolnośćc } \\
\text { do inkubacji } \\
\text { nowych } \\
\text { graczy }\end{array}$ & Suma \\
\hline Polska & + & + & ++ & + & - & 4 \\
\hline Chiny & ++ & + & ++ & ++ & ++ & 8 \\
\hline Norwegia & + & ++ & 0 & ++ & - & 4 \\
\hline Niemcy & - & + & - & + & + & 1 \\
\hline USA & 0 & + & + & 0 & ++ & 4 \\
\hline Francja & 0 & + & - & + & 0 & 1 \\
\hline $\begin{array}{l}\text { Wlk. } \\
\text { Brytania }\end{array}$ & + & + & 0 & + & - & 2 \\
\hline
\end{tabular}

Skala od oceny najgorszej do najlepszej: $-, 0,+,++$

Źródło: opracowanie własne.

W efekcie wyłania się pewna hierarchia krajów posiadających najlepsze warunki do upowszechniania elektromobilności. Najlepiej spozycjonowane do skorzystania na rewolucji elektromobilności wydają się Chiny. Wielkość rynku, zdolność do wsparcia pionierów, korzyści wynikające z globalnej rewolucji technologicznej predestynują ten kraj do objęcia globalnego przywództwa w zakresie elektryfikacji transportu. Fakt, iż co drugi pojazd elektryczny na świecie sprzedaje się właśnie w Chinach i tutaj budują się największe fabryki ogniw litowo-jonowych, a przedsiębiorstwa, takie jak BYD, dominują na światowym rynku autobusów elektrycznych, potwierdza tę diagnozę. Wysoko w rankingu, i to z różnych powodów, sytuują się USA, Norwegia i Polska: USA jako globalny lider technologiczny i najbardziej innowacyjna gospodarka świata; Norwegia, silna bogactwem i oczekiwaniami swoich mieszkańców; Polska zaś skutecznie aspirująca do grona przemysłowych tygrysów XXI wieku. Wielka Brytania znajduje się w środku stawki, natomiast w najmniej sprzyjającej sytuacji wydają się znajdować Niemcy i Francja, gdzie elektromobilność oznacza konfrontację z tradycyjnym przemysłem w kontekście bardzo niepewnej walki o utrzymanie globalnej supremacji. 


\section{Podsumowanie}

Należy podkreślić, iż powyższe porównanie ma charakter poglądowy i schematyczny. Wymaga weryfikacji empirycznej. Jego wartością jest fakt, iż wskazuje na czynniki, które mogą zaważyć na sukcesie danego kraju i jego firm, nazwanej synergiczną kooperacją. Na przykładzie samej tylko elektromobilności pokazuje różne motywacje i różne bariery, które mogą stać się udziałem państw na drodze do sięgnięcia po realizację potencjału wartości, jaki wyłoni się z nałożenia się czterech trendów, które ukształtują przemysł samochodowy współczesności: autonomizacji, urbanizacji, cyfryzacji i elektryfikacji.

Wiele wskazuje bowiem, że to właśnie synergiczna współpraca pomiędzy państwem i sektorem prywatnym będzie warunkiem skorzystania z szans, jakie rysują się w zakresie nowej mobilności. W większości państw świata te szanse pozostaną niezagospodarowane, ale tam gdzie uda się po nie sięgnąć nagrodą będzie konkurencyjny przemysł, wysoko płatne miejsca pracy i globalna renta wynikająca z przewagi technologicznej.

\section{Bibliografia}

BCG. (2018). Analiza rynku elektromobilności i jego potencjatu. Warszawa: The Boston Consulting Group.

CCAC. (2018). Briefing Paper by Climate and Clean Air Coalition for G7 Environment Ministers' Meeting on Urgent Action and Reduction Opportunities. Halifax, Canada: Climate and Clean Air Coalition.

Fukuyama, F. (2018). Against identity politics. Pozyskano z: https://www.foreignaffairs.com/ articles/americas/2018-08-14/against-identity-politics.

Hampleton Partners. (2018). Artificial Intelligence AI market report. Pozyskano z: https:// hampletonpartners.com/mediaarticle/hampleton-partners-artificial-intelligence-ai-marketreport/.

Harrari, Y. (2018). Homo Deus. Warszawa: Wydawnictwo Literackie.

IEA. (2018) Global EV Outlook. Paris: International Energy Agency.

Kurzweil, R. (2013). Nadchodzi osobliwość. Warszawa: Kurhaus Publishing.

Morgan Stanley. (2018). 5 acquisition trends investors should watch in 2018. Pozyskano z: https://www.morganstanley.com/ideas/5-acquisition-trends-investors-should-watchin-2018.

Piketty, Th. (2013). Le Capital au XXIe siècle. Paris: Edition de Seuil.

Roser, M. (2018). The short history of global living conditions and why it matters that we know it. Pozyskano z: www.ourworldindata.org.

UNGC (2016). Zrównoważone miasta. Życie w zdrowej atmosferze. Warszawa: United Nations Global Compact. Pozyskano z: http://ungc.org.pl/programy/zrownowazone-miasta/Miasta zrównoważone. 